\title{
PROSES BERPIKIR KREATIF SISWA SMP YANG MENGIKUTI BIMBINGAN BELAJAR DALAM MENYELESAIKAN SOAL-SOAL UJIAN NASIONAL
}

\author{
${ }^{1}$ Natalia Desi A., ${ }^{2}$ Sardulo Gembong, ${ }^{3}$ Tri Andari \\ ${ }^{1}$ Mahasiswa Prodi Matematika IKIP PGRI Madiun \\ ${ }^{2}$ Dosen Prodi Matematika IKIP PGRI Madiun \\ ${ }^{3}$ Dosen Prodi Matematika IKIP PGRI Madiun
}

\begin{abstract}
Abstrak. Dalam menyelesaikan soal-soal ujian nasional matematika, siswa yang mengikuti bimbingan belajar memiliki kemampuan berpikir kreatif yang baik. Dengan mengikuti bimbingan belajar sangat membantu siswa dalam menyelesaikan kesulitan-kesulitan yang mereka temukan saat menyelesaikan soal-soal dalam menghadapi ujian nasional. Proses bepikir kreatif merupakan suatu proses aktivitas mental yang terkait dengan kepekaan terhadap masalah, mempertimbangkan informasi baru dan ide-ide yang tidak biasanya dengan suatu pikiran terbuka. Dalam berpikir kreatif ada 5 tahapan yang harus dilewati yaitu orientasi, inkubasi, iluminasi, verifikasi, dan aplikasi.

Penelitian ini bertujuan untuk mengetahui bagaimana proses berpikir siswa SMP yang mengikuti bimbingan belajar ketika menyelesaikan soal-soal ujian nasional. Jenis penelitian ini adalah penelitian kualitatif dan penelitian dilakukan pada 6 orang siswa SMP yang mengikuti bimbingan belajar di luar sekolah yang dibagi menjadi 3 kategori yaitu kategori tinggi, kategori sedang, dan kategori rendah yang masing-masing kategori berjumlah dua orang siswa. Teknik pengumpulan data pada penelitian ini yaitu menggunakan metode tes dan wawancara sedangkan teknik keabsahan data penelitian ini mengunakan teknik triangulasi teknik. Pada penelitian ini peneliti dalam menganalisis data menggunakan 3 komponen yaitu reduksi data, sajian data, penarikan kesimpulan dan verifikasi.

Hasil penelitian yang dilakukan menunjukan bahwa pada tahap (1) orientasi: a. semua subyek kategori tinggi, sedang dan rendah mampu mengumpulkan informasi dengan baik. b. Mengidentifikasi masalah, subjek kategori tinggi dan sedang dapat mengidentifikasi masalah dengan baik, sedangkan pada kategori rendah dapat mengidentifikasi masalah dengan cukup. (2) inkubasi: subyek kategori tinggi dan sedang mampu melewati dengan baik sedangkan subyek kategori rendah mampu melewatinya dengan cukup. (3) iluminasi: subyek kategori tinggi dapat menemukan ide atau inspirasi dengan baik, subyek kategori sedang belum dapat disimpulkan secara umum. (4) verifikasi:a. Mengevaluasi pemecahan masalah, subyek kategori tinggi dan sedang mampu mengevaluasi pemecahan masalah baik, sedangkan subyek kategori rendah belum dapat disimpulkan secara umum, b. Memutuskan solusi, semua subyek dapat memutuskan solusi dengan baik. (5) aplikasi: semua subyek mengambil langkah-langkah solusi dengan cukup.
\end{abstract}

Kata kunci: Proses, Berpikir Kreatif, Bimbingan Belajar, Ujian Nasional.

\section{PENDAHULUAN}

Dalam dunia pendidikan, ujian nasional sudah tidak asing lagi di telinga kita. Menurut Peraturan Menteri Pendidikan dan Kebudayaan Nomor 3 Tahun 2013 Pasal 1 tentang ujian nasional, dijelaskan bahwa ujian nasional adalah kegiatan pengukuran dari penilaian kompetensi siswa yang dilakukan oleh sekolah untuk semua mata pelajaran pada pokok ilmu pengetahuan dan teknologi. Ujian nasional dilaksanakan di berbagai tingkatan dalam pendidikan yaitu SD, SMP dan SMA. Ujian nasional sudah menjadi salah satu penentu mutlak kelulusan siswa. Menurut BSNP (Badan Standar Nasional Pendidikan) kriteria kelulusan peserta didik untuk tahun ajaran 2012/2013 ini yang dilaksanakan di tingkat SMP yaitu nilai rata-rata dari 
semua nilai akhir mencapai paling rendah 5,5 (lima koma lima) dan nilai setiap mata pelajaran paling rendah 4,0 (empat koma nol).

Sesuai dengan tujuan ujian nasional menurut Keputusuan Menteri Pendidikan No. 153/U2003 tentang ujuan nasional, disana disebutkan bahwa tujuan ujian nasional adalah untuk mengukur pencapaian hasil belajar siswa melalui pemberian tes pada siswa sekolah lanjutan tingkat pertama dan sekolah lanjutan tingkat atas. Ujian nasional berfungsi sebagai alat pengendali mutu pendidikan secara nasional, pendorong peningkatan mutu pendidikan secara nasional, bahkan pertimbangan dalam seleksi penerimaan jenjang pendidikan yang lebih tinggi, dan sebagai bahan dalam menentukan kelulusan siswa.

Hasil observasi yang dilakukan oleh peneliti pada beberapa siswa SMP kelas IX di Kota Madiun, diperoleh data bahwa mereka mengalami kesulitan dalam menyelesaikan soal-soal ujian nasional. Hal tersebut dikarenakan kurangnya waktu yang disediakan oleh sekolah dalam mengekplor kemampuan berpikir siswa sehingga pemahaman dalam proses berpikir juga lemah. Apalagi dengan semakin dekatnya ujian nasional, banyak orang tua dari siswa tersebut yang merasa khawatir akan nilai hasil ujian nasional dari anak mereka. Untuk mengatasi masalah tersebut, kebanyakan dari mereka memilih memasukkan anaknya ke bimbingan belajar di luar jam sekolah sebagai salah satu solusi cepat untuk mengatasi permasalahan tersebut. Dan hasilnya $84 \%$ dari mereka mengalami peningkatan dalam proses berpikir. Hal tersebut dibuktikan dengan hasil tryout yang mengalami peningkatan. Bahkan ketika diwawancarai, mereka mengungkapkan bahwa ketika mereka mengikuti bimbingan belajar di luar jam sekolah, banyak trik-trik cepat yang mereka peroleh untuk mempermudah menyelesaikan soal ujian nasional.

Banyak manfaat yang bisa diperoleh siswa dengan mengikuti bimbingan belajar. Mereka akan terbantu untuk memahami pelajaran yang belum begitu dipahami atau dikuasainya. Dengan mengikuti bimbingan belajar siswa dapat bertanya dan berdiskusi tentang segala sesuatu yang dirasa masih membingungkannya. Disini mereka juga akan mendapatkan jawaban-jawaban yang praktis. Praktis disini maksudnya adalah cara sederhana yang lebih menyingkat waktu untuk menjawab soal-soal tersebut. Dengan mengikuti bimbingan belajar dapat meningkatkan kemampuan berpikir kreatif pada siswa.

Pada dasarnya setiap orang itu kreatif, walaupun tentu dengan tingkat yang berbeda atau dengan cara pengekspresian yang berbeda. Hanya saja, orang tua dan guru perlu menyediakan lingkungan yang benar untuk membebaskan seluruh potensi kreatifnya sehingga terjadi proses pembelajaran yang berpusat pada anak. Belajar mengembangkan kemampuan berpikir kreatif tidak hanya dilaksanakan pada pendidikan formal, akan tetapi dapat dilaksanakan pada pendidikan non formal seperti bimbingan belajar. Melalui kedua lingkup pendidikan tersebut, diharapkan siswa dapat menumbuhkan kemampuan berpikir kreatif, kritis, logis, sistematis, cermat, efektif, dan efisien dalam memecahkan masalah.

Ada Banyak faktor yang mungkin menyebabkan rendahnya kemampuan berpikir kreatif siswa dalam pelajaran matematika. Faktor-faktor tersebut dapat berupa faktor berpikir siswa, minat, motivasi, dan genetika. Faktor eksternal meliputi guru, alat belajar, kondisi lingkungan keluarga ataupun teman. Dengan mengikuti bimbingan belajar di luar sekolah ternyata mempengaruhi proses berpikir kreatif siswa. Jika dibandingkan dengan siswa yang hanya mendapatkan bimbingan di dalam sekolah saja, siswa yang mengikuti bimbingan belajar diluar sekolah lebih bisa berpikir kreatif.

Berpikir kreatif merupakan salah satu cara yang dianjurkan. Dengan 
cara itu seseorang akan mampu melihat persoalan dari banyak perspektif. Pasalnya, seorang pemikir kreatif akan menghasilkan lebih banyak alternatif untuk memecahkan suatu masalah. Melalui bimbingan belajar, diharapkan dapat meningkatkan kemampuan berpikir kreatif siswa dalam menyelesaikan soal-soal ujian. Dari berbagai uraian di atas, maka penulis tertarik untuk melakukan penelitian tentang proses berpikir kreatif siswa smp yang mengikuti bimbingan belajar dalam menyelesaikan soal-soal ujian nasional.

\section{Kajian Teori}

\section{Berpikir Kreatif}

Menurut Ngalim Purwanto (2007: 43) "berpikir adalah daya yang paling utama dan merupakan ciri yang khas yang membedakan manusia dan hewan". Dewey dan Wertheimer (dalam Slameto, 2010: 144) "memandang berpikir sebagai proses". Sedangkan Plato (dalam Sumadi, 1990: 54) beranggapan bahwa berpikir itu adalah berbicara dalam hati.

Berpikir berasal dari kata "pikir" yang dalam Kamus Besar Bahasa Indonesia (1999: 767) berarti "akal budi, ingatan, angan-angan". Menurut Wowo Sunaryo (2011: 1) "berpikir artinya menggunakan akal budi untuk mempertimbangkan dan memutuskan sesuatu, menimbang- nimbang dalam ingatan".

Gilmer (dalam Wowo Sunaryo, 2011:2) menjelaskan bahwa "berpikir merupakan suatu pemecahan masalah dan proses penggunaan gagasan atau lambang-lambang pengganti suatu aktivitas yang tampak secara fisik". Sedangkan Agus Sujanto (2004: 56) mendefinisikan "berpikir ialah gejala jiwa yang dapat menetapkan hubunganhubungan antara ketahuan-ketahuan kita".

John W. Santrock (2007: 357) menjelaskan "berpikir adalah memanipulasi atau mengelola dan mentransformasi dalam memori”. Sesuai hukum Gestalt (dalam Sarlito, 2009: 107) bahwa "manusia berpikir secara menyeluruh, maka proses belajar yang terutama melibatkan proses berpikir, harus dimulai dengan mempelajari materi secara keseluruhan, baru ke detail atau bagian-bagiannya (menghafal kalimat-kalimat, rumus-rumus atau dalil-dalil)". Oleh sebab itu dalam berpikir melibatkan proses memanipulasi informasi secara mental (King, 2010: 7).

Dalam bukunya Teori Belajar Dewasa, Anisah dan Syamsu Mappa (2011: 37) mendefinisikan "berpikir adalah suatu kegiatan mental yang berupa upaya melukiskan gagasan berdasarkan pengetahuan yang dimiliki dengan memperhitungkan hubungan sebab akibat dan dirangkaikan secara logis dan rasional". Sedangkan Mussen dan Rosenzweig (dalam Jalaludin Rakhmat, 2007: 68 ) mengatakan "The term 'thinking' refers to many kind of aktivities that involve the manipulation of concepts and symbols, representations of objects and events". Jadi, berpikir menunjukkan berbagai kegiatan yang melibatkan penggunaan konsep dan lambang, sebagi pengganti objek dan peristiwa.

Dari berbagai definisi-definisi diatas, maka dapat disimpulkan bahwa pengertian berpikir adalah aktivitas mental untuk menghasilkan penemuan yang terarah pada pemahaman yang diinginkan dengan melibatkan interaksiinteraksi mental secara kompleks seperti penilaian, abstraksi, penalaran, imajinasi dan pemecahan masalah.

\section{Proses Berpikir}

Ngalim Purwanto (2007: 43) berpendapat bahwa ciri utama dari berpikir adalah adanya abstraksi. Dalam berpikir, abstraksi adalah suatu anggapan dimana lepasnya kualitas atau relasi dari benda-benda, kejadiankejadian dan situasi-situasi yang mulamula dihadapi sebagai kenyataan dalam pikiran kita. "Proses berpikir merupakan urutan kejadian mental yang terjadi secara alamiah atau terencana dan 
sistematis pada konteks ruang waktu, dan media yang digunakan" (Wowo Sunaryo, 2011: 3). Menurut Abdul Rahman (2009: 229) "dalam proses berpikir orang menghubungkan pengertian satu dengan pengertian lain untuk mendapatkan pemecahan masalah dari persoalan yang dihadapi".

Menurut Floyd (dalam Wowo Sunaryo, 2011: 7) membedakan berpikir menjadi tiga esensi, yaitu :1) Berpikir deduktif Merupakan proses berpikir yang dimulai dari hal-hal yang bersifat umum pada hal-hal yang bersifat khusus. Dalam logika, ini disebut dengan silogisme. 2) Berpikir induktif Merupakan kebalikan dari berpikir deduktif yaitu proses pengambilan keputusan dimulai dari hal-hal yang bersifat khusus menuju umum. Istilah ini dikenal dengan generalisasi. 3) Berpikir evaluative Proses berpikir secara kritis untuk menilai baik atau buruk, tepat atau tidak, bahkan bermanfaat atau tidaknya sebuah gagasan. Seperti yang dikemukakan Guilford (dalam Slameto, 2010: 144) bahwa "ada tiga komponen pokok dalam berpikir yaitu : pengerjaan (operations), isi (contens) dan hasil (product)". Selama kita berpikir, kita akan melalui beberapa proses. Menurut Sumadi Suryabrata (2004: 54), dalam proses berfikir ada tiga langkah, yaitu : pembentukan pengertian, membentuk pendapat, penarikan kesimpulan atau pembentukan keputusan.

Pembentukan pengertian Pengertian atau lebih tepatnya disebut pengertian logis dibentuk melalui tiga tingkatan, sebagai berikut : a) Menganalisis ciri-ciri dari sejumlah objek yang sejenis. b) Membanding-bandingkan ciri-ciri tersebut untuk diketeemukan ciri-ciri mana yang sama, mana yang tidak sama, mana yang selalu ada dan mana yang selalu tidak ada, mana yang hakiki dan yang mana yang tidak hakiki. c) Mengabstraksikan yaitu menyisihkan, membuang, ciri-cirinya yang tidak hakiki, menangkap ciri-cirinya yang hakiki. Membentuk Pendapat Membentuk pendapat adalah meletakkan hubungan antara dua buah pengertian atau lebih. Pendapat itu sendiri dibedakan menjadi tiga macam, yaitu: a) Pendapat alternatif atau positif Pendapat alternatif/positif adalah pendapat yang menyatakan keadaan sesuatu. b) Pendapat negatif Pendapat negatif adalah pendapat yang menidakkan, yang secara tegas menerangkan tentang tidak adanya sesuatu sifat pada sesuatu hal. c) Pendapat modalitas atau kebarangkalian Pendapat modalitas atau kebarangkalian adalah pendapat yang menerangkan kebarangkalian, kemungkinankemungkinan sesuatu sifat pada sesuatu hal. Penarikan Kesimpulan atau Pembentukan Keputusan Keputusan adalah hasil perbuatan akal untuk membentuk pendapat baru berdasarkan pendapat-pendapat yang telah ada. Terdapat 3 macam keputusan, yaitu : a) Keputusan Induktif Keputusan induktif adalah keputusan yang diambil dari pendapat-pendapat yang khusus menuju ke suatu pendapat umum. b) Keputusan Deduktif Keputusan deduktif adalah keputusan yang ditarik dari pendapatpendapat yang umum ke hal yang khusus. c) Keputusan Analogis Keputusan analogis adalah keputusan yang diperoleh dengan jalan membandingkan atau menyesuaikan dengan pendapat-pendapat khusus yang telah ada.

Bayley (dalam Slameto, 2010: 131) di dalam studinya menemukan beberapa faktor yang mempengaruhi kemampuan intelektual individu, yaitu :1) Keturunan, Studi korelasi nilai-nilai tes intelegensi anatara anak dan orang tua, atau dengan kakek-neneknya, menunjukkan adanya pengaruh faktor keturunan terhadap tingkat kemampuan mental seseorang sampai pada tingkat tertentu. 2) Latar belakang sosial ekonomi, Pendapatan keluarga, pekerjaan orang tua dan faktor-faktor sosial ekonomi lainnya, korelasi positif dan cukup tinggi dengan taraf kecerdasan individu mulai usia 3 tahun sampai dengan remaja. 3) Lingkungan hidup, Lingkungan yang kurang baik akan menghasilkan kemampuan 
intelektual yang kurang baik pula. Lingkungan yang dinilai paling buruk bagi perkembangan intelegensi adalah panti-panti asuhan serta institusi lainnya, terutama bila anak ditempatkan disana sejak awal kehidupannya. 4) Kondisi fisik, Keadaan gizi yang kurang baik, kesehatan yang buruk, perkembangan fisik yang lambat, menyebabkan tingkat kemampuan mental yang rendah. 5) Iklim emosi, Iklim emosi di mana individu dibesarkan mempengaruhi perkembangan mental individu yang bersangkutan.

\section{Berpikir Kreatif}

Menurut Mustaqim dan Abdul (2003: 95) "berpikir kreatif mengandung proses mental yang dipergunakan juga dalam bentuk-bentuk berpikir yang lain seperti pengalaman, asoaial ekspresi, impresi atau kesan mental diterima, diingat kembali direfleksikan dan dipergunakan".

Sejalan dengan pendapat Slameto (2010: 145) "pengertian kreatif berhubungan dengan penemuan sesuatu, mengenai hal yang menghasilkan sesuatu yang baru dengan menggunakan sesuatu yang telah ada".

Jadi dapat disimpulkan bahwa berpikir kreatif itu adalah proses kemampuan seseorang dalam memahami suatu masalah sehingga memunculkan gagasan-gagasan atau ide-ide baru.

Secara umum faktor-faktor yang menandai orang-orang kreatif menurut Coleman dan Hammen ( dalam Jalaluddin, 2007: 77) yaitu: 1) Kemampuan kognitif, Kemampuan kognitif disini adalah kecerdasan di atas rata-atas, kemampuan melahirkan gagasan-gagasan baru, gagasan-gagasan yang berlainan, dan fleksibilitas kognitif. 2) Sikap yang terbuka Orang yang kreratif dapat menerima stimulus internal dan eksternal. Ia memiliki minat yang beragam dan luas dan rendah diri (humble). 3) Sikap yang bebas, otonom, dan percaya pada diri sendiri Orang kreatif tidak senang didikte, mereka selalu ingin menampilkan dirinya sendiri semampunya dan tidak terlalu terikat pada konvensi-konvensi sosial.

Dari beberapa pendapat di atas dapat disimpulkan bahwa berpikir kreatif adalah aktivitas mental yang terkait dengan kepekaan terhadap masalah, mempertimbangkan informasi baru dan ide-ide yang tidak biasanya dengan suatu pikiran terbuka, serta dapat membuat hubungan-hubungan dalam menyelesaikan masalah tersebut.

Kemampuan kreatif secara umum dipahami sebagai kreativitas. Seringkali, individu yang dianggap kreatif adalah pemikir sintesis yang benar-benar baik yang membangun koneksi antara berbagai hal yang tidak disadari orang-orang lain secara spontan.

Ciri-ciri peserta didik yang kreatif menurut Munandar (dalam Sudarwan Danim, 2011: 136) adalah : 1) Senang mencari pengalaman baru. 2) Memilii keasyikan dalam mengerjakan tugas-tugas yang sulit. 3) Memiliki inisiatif. 4) Memiliki ketekunan yang tinggi. 5) Cenderung kritis terhadap orang lain. 6) Berani menyatakan pendapat dan keyakinannya. 7) Selalu ingin tahu. 8) Peka atau perasa. 9) Enerjik dan ulet. 10) Menyukai tugastugas yang majemuk. 11) Percaya kepada diri sendiri. 12) Mempunyai rasa humor. 13) Memiliki rasa keindahan. 14) Berwawasan masa depan dan penuh imajinasi.

Sedangkan menurut Torrance (dalam M. Ali dan Asrori, 2005: 53), beliau mengemukakan karakteristik kreativitas seperti berikut ini : 1) Memiliki rasa ingin tahu yang besar. 2) Tekun dan tidak mudah bosan. 3) Percaya diri dan mandiri. 4) Merasa tertantang oleh kemajemukan atau kompleksitas. 5) Berani mengambil resiko. 6) Berpikir divergen.

Menurut Jalaluddin (2007: 76) para psikolog menyebutkan lima tahap berpikir kreatif, yaitu orientasi, preparasi, inkubasi, iluminasi dan verifikasi. 1) Orientasi, Masalah dirumuskan, dan aspek-aspek masalah 2) Preparasi, Seseorang mengumpulkan 
informasi atau data untuk memecahkan suatu masalah dan juga waktu untuk mendefinisikan masalah. 3) Inkubasi, Proses pemecahan masalah "dierami" dalam pikiran bawah sadar sampai timbul inspirasi atau ide untuk memecahkan masalah. 4) Iluminasi, Masa inkubasi berakhir ketika pemikir memperoleh semacam ilham atau ide telah muncul, serangkaian insight yang memecahkan masalah. 5)Verifikasi, Tahap mengevaluasi secara kritis dan menghadapkannya kepada realitas inspirasi atau gagasan yang telah muncul. Pada tahap ini saatnya memutuskan jika solusi itu benar-benar memecahkan masalah.

Dalam tahap berpikir kreatif, ada langkah-langkah yang harus dilalui agar seseorang dapat menemukan sesuatu yang baru. Menurut Wallas (dalam Oemar Hamalik, 1992: 147), langkah-langkah yang harus dilalui yaitu: 1) Preparasi (persiapan). Pada tahap ini, seorang individu mengalami proses menelaah masalah, lalu timbul pertanyaan-pertanyaan, menyerap informasi yang telah dikumpulkan agar dapat menemukan cara pemecahan masalah tersebut. 2) Inkubasi, yaitu individu memerlukan waktu untuk mematangkan ide-ide yang telah ditemukan. Individu membutuhkan waktu untuk istirahat dan menghilangkan ketegangannya serta waktu untuk memproses pikirannya agar mendapat ide-ide yang kreatif. 3) Iluminasi, yaitu tahapan dimana individu mencapai pemahaman dalam bagaimana menerapkan konsep yang telah ditemukan ke dalam pemecahan masalah.

Verifikasi atau revisi, yaitu tahapan individu untuk mengecek kembali pemecahan yang telah dilakukan.

Sedangkan menurut Sufyan Ramadhy (2009: 125-126), tahapantahapan yang paling diterima luas dewasa ini adalah tahapan kreatif dari Wallas, yaitu: 1) Tahap persiapan, Seseorang mengumpulkan informasi atau data untuk memecahkan suatu masalah dan juga waktu untuk mendefinisikan masalah. 2) Tahap inkubasi, Proses pemecahan masalah "dierami" dalam pikiran bawah sadar. Seseorang seakan-akan melupakannya. Tahap ini berlangsung lama (berharihari sampai bertahun-tahun), tetapi juga bisa berlangsung singkat (beberapa menit atau jam), sampai timbul inspirasi atau ide untuk memecahkan masalah. 3) Tahap Iluminasi, Tahap inspirasi atau ide telah muncul. Kohler melukiskan tahap ini dengan kata "Aha, Erlebnis!". 4) Tahap Verifikasi, Tahap mengevaluasi secara kritis dan menghadapkannya kepada realitas inspirasi atau gagasan yang telah muncul. Pada tahap ini saatnya memutuskan jika solusi itu benar-benar memecahkan masalah. 5) Tahap aplikasi Tahap untuk mengambil langkahlangkah untuk mengikuti solusi.

\section{Proses Berpikir Kreatif Siswa SMP}

Masa remaja merupakan masa peralihan dari masa kanak-kanak ke masa dewasa. Menurut Mussen, Conger \& Kagan (dalam Desmita, 2012:194) masa renaja adalah suatu periode kehidupan dimana kapasitas untuk memperoleh dan menggunakan pengetahuan secara efisien mencapai puncaknya. Slameto (2010: 50) "pada masa remaja anak telah mulai berpikir secara abstrak". Beliau juga menjelaskan kecakapan anak pada usia lebih dari 11 tahun tidak lagi terbatas pada objek-objek yang konkret serta dapat memandang kemungkinankemungkinan yang ada melalui pemikiranya, dapat mengorganisasikan situasi/masalah, dan dapat berpikir dengan betul ( dapat berpikir logis, mengerti hubungan sebab akibat, memecahkan masalah/berpikir secara alamiah)

Menurut Piaget (dalam Desmita, 2012: 195) pemikiran operasional formal dimulai pada usia 11 atau 12 tahun dan terus berlanjut sampai dewasa. Pada tahap perkembangan kognitif, anak sudah mampu memikirkan sesuatu yang akan atau mungkin terjadi (abstrak). Remaja sudah 
mampu berpikir secara sistematik dalam memecahkan suatu masalah, memecahkan masalah dengan membuat perencanaan kegiatan terlebih dahulu dan berusaha mengantisipasi berbagai macam informasi yang akan diperlukan untuk memecahkan masalah tersebut. Selain itu, remaja sudah mampu memahami keberagaman aspek pada suatu persoalan yang dapat diselesaikan sekaligus, tidak lagi satu-persatu.

\section{Bimbingan Belajar}

Dalam belajar siswa membutuhkan bimbingan. Bimbingan ini perlu diberikan untuk mencegah usaha-usaha yang membuta, hingga anak tidak mengalami kegagalan, dengan bimbingan dapat menghindarkan kesalahan-kesalahan dan memperbaikinya. Abin Syamsuddin (2009: 277) mendefinisikan pengertian layanan bimbingan sebagai berikut : a) Layanan bimbingan (guidance services) merupakan bantuan yang diberikan kepada individu tertentu. b) Layanan bimbingan bertujuan agar yang bersangkutan dapat mencapai taraf perkembangan dan kebahagiaan secara optimal. c) Dengan layanan bimbingan, kita dapat menjalani proses pengenalan, pemahamann, penerimaan, pengarahan, perwujudan, serta penyesuaaian diri, baik terhadap dirinya sendiri maupun terhadap lingkungannya.

Menurut Ketut Sukardi (2012: 40) mendefinisikan bimbingan belajar adalah bimbingan dalam hal menemukan cara belajar yang tepat, dalam memilih program studi sesuai,dan dalam mengatasi kesukaran kesukaran yang timbul berkaitan dengan tuntunantuntunan belajar disuatu institusi pendidikan .

Sementara itu, tujuan diadakannya bimbingan belajar adalah sebagai berikut : a) Agar siswa memiliki sikap dan kebiasaan belajar yang positif, seperti kebiasaan membaca buku, disiplin dalam belajar, mempunyai perhatian terhadap semua pelajaran, dan aktif mengikuti semua kegiatan belajar yang diprogramkan. b) Memiliki motif yang tinggi untuk belajar sepanjang hayat. c) Memiliki keterampilan atau teknik belajar yang efektif, seperti keterampilan membaca buku, menggunakan kamus, mencatat pelajaran, dan mempersiapkan diri menghadapi ujian. d)Memiliki keterampilan menetapkan tujuan dan perencanaan pendidikan, seperti membuat jadwal belajar, mengerjakan tugas-tugas, memantapkan diri dalam pelajaran tertentu, dan berusaha memperoleh informasi tentang berbagai hal dalam rangka mengembangkan wawasan yang lebih luas. e) Memiliki kesiapan mental dan kemampuan untuk menghadapi ujian.

Secara umum tujuan diadakannya bimbingan belajar adalah untuk membantu murid-murid agar mendapat penyesuaian yang baik di dalam situasi belajar, sehingga setiap murid dapat belajar dengan efisien sesuai dengan kemampuan yang dimilikinya, dan mencapai perkembangan yang optimal.

\section{Ujian Nasional}

Menurut Peraturan Menteri Pendidikan dan Kebudayaan Nomor 3 Tahun 2013 Pasal 1 tentang ujian nasional, dijelaskan bahwa ujian nasional adalah kegiatan pengukuran dari penilaian kompetensi peserta didik yang dilakukan oleh sekolah untuk semua mata pelajaran pada pokok ilmu pengetahuan dan teknologi. Sesuai dengan tujuan ujian nasional menurut Keputusuan Menteri Pendidikan No. 153/U2003 tentang ujuan nasional, disana disebutkan bahwa tujuan ujian nasional adalah untuk mengukur pencapaian hasil belajar peserta didik melalui pemberian tes pada siswa sekolah lanjutan tingkat pertama dan sekolah lanjutan tingkat atas.

Kriteria kelulusan peserta didik untuk tahun ajaran 2012/2013 ini untuk UN yang dilaksanakan di tingkat SMP yaitu nilai rata-rata dari semua nilai akhir mencapai paling rendah 5,5 (lima koma lima) dan nilai setiap mata 
pelajaran paling rendah 4,0 (empat koma nol).

Berikut ini adalah mata pelajaran yang akan di ujikan tahun 2013 menurut Badan Nasional Standar Pendidikan (BNSP) yakni:

Tabel 1. Mata Pelajaran Ujian Nasional 2012/2013

\begin{tabular}{|l|l|c|c|}
\hline No & \multicolumn{1}{|c|}{ Mata Ujian } & $\begin{array}{c}\text { Jumlah } \\
\text { Butir } \\
\text { Soal }\end{array}$ & $\begin{array}{c}\text { Alokasi } \\
\text { Waktu } \\
\text { (menit) }\end{array}$ \\
\hline 1. & Bahasa Indonesia & 50 & 120 menit \\
\hline 2. & Matematika & 40 & 120 menit \\
\hline 3. & Bahasa Inggris & 50 & 120 menit \\
\hline 4. & $\begin{array}{l}\text { Ilmu Pengetahuan } \\
\text { Alam (IPA) }\end{array}$ & 40 & 120 menit \\
\hline
\end{tabular}

Kisi-kisi soal ujian nasional untuk SMP/MTS tahun pelajaran 2012/2013 adalah berikut ini :

\section{Matematika}

"Matematika adalah suatu alat untuk mengembangkan cara berpikir" (Herman Hudojo, 2005: 35). Matematika berkenaan dengan ideide/konsep-konsep abstrak yang tersusun secara hirarkis dan penalarannya deduktif.

Sukardjono (2007:13) dalam bukunya Hakikat dan Sejarah Matematika, menjelaskan pengertian matematika adalah sebagai berikut : a) Cara atau metode berpikir dan bernalar. b) Suatu medan eksplorasi dan penemuan, di situ setiap hari ide-ide baru ditemukan. c) Metode berpikir yang digunakan untuk memecahkan semua jenis permasalahan yang terdapat di dalam sains, pemerintahan, dan industri. d) Bahasa lambang yang dapat dipahami oleh semua bangsa berbudaya. e) Seni, seperti pada musik, penuh dengan simetri, pola, dan irama yang dapat sangat menghibur.

Begle (dalam Herman Hudojo, 2005: 36) menjelaskan bahwa sasaran atau obyek penelaah matematika yaitu fakta, konsep, operasi dan prinsip. Sedangkan Bandi Delphie (2009: 2) berendapat bahwa "matematika adalah bahasa simbolis yang memiliki fungsi praktis untuk mengekspresikan hubungan-hubungan kuantitatif dan keruangan". Pada hakikatnya, berpikir matematik itu dilandasi oleh kesepakatan-kesepakatan yang disebut aksioma

Matematika tumbuh dan berkembang karena proses berpikir, oleh karena itu logika adalah dasar untuk terbentuknya matematika. Jadi, untuk dapat mengetahui apa matematika itu sebenarnya, seseorang harus mempelajari sendiri ilmu matematika itu, yaitu dengan mempelajari, mengkaji, dan mengerjakannya. Termasuk pengkajian sejauh timbulnya matematika dan perkembangannya.

Dari uraian di atas dapat disimpulkan bahwa matematika adalah ilmu yang menggunakan simbol yang berkenaan dengan ide - ide atau konsep - konsep yang bersifat abstrak dan menggunakan penalaran deduktif.

Menurut Polya (dalam Endang S. W dan Sri Harmini: 2011) masalah matematika dikelompokkan menjadi beberapa macam yaitu : a) Masalah untuk menemukan, dapat teoretis atau praktis, konkret atau abstrak, termasuk teka-teki. Pada masalah ini kita harus merumuskan inti dari masalah yang kemudian akan digunakan sebagai landasan dalam menyelesaikan masalah. b) Masalah yang berkaitan dengan membuktikan adalah untuk menunjukan bahwa suatu penyataan itu benar atau salah dan tidak keduanya.

\section{Pemecahan Masalah Matematika}

Lester (dalam Endang dan Sri Harmini, 2011: 116) mengartikan masalah sebagai suatu situasi dimana individu atau kelompok terpanggil untuk melakukan suatu tugas dimana tidak tersedia algoritma yang secara lengkap menentukan penyelesaian masalahnya.

Menurut John Dewey (dalam Oemar Hamalik, 1992: 145) menganalisis aspek-aspek pemecahan masalah, yaitu : adanya kebutuhan yang dirasakan (felt need) pada individu. Mengenal dan merumuskan masalah sekhusus mungkin. Mengumpulkan data. Merumuskan hipotesis.Menguji hipotesis. Merumuskan generalisasi.

Jadi pemecahan masalah adalah proses untuk menemukan kombinasi 
dari sejumlah aturan yang dapat diterapkan dalam upaya mengatasi situasi yang baru (Made Wena, 2011: $52)$.

Kramers (Made Wena, 2011: 60) mengemukakan secara operasional tahap-tahap pemecahan masalah sistematis terdiri atas empat tahap berikut: Memahami masalahnya. Membuat rencana penyelesaian. Melaknasanakan rencana penyelesaian. Memeriksa kembali, mengecek hasilnya.

Penyusunan pemecahan masalah sistematis juga harus memperhatikan beberapa prosedur seperti yang dikemukan oleh Giancoli (dalam Made Wena, 2011: 63) berikut : Baca masalah secara menyeluruh dan hati-hati sebelum mencoba untuk memecahkannya. Tulis apa yang diketahui atau yang diberikan, kemudian tuliskan apa yang akan ditanyakan. Pikirkan tentang prinsip, definisi, dan/atau persamaan hubungan besaran yang berkaitan. Pikirkanlah dengan hati-hati tentang hasil yang diperoleh, apakah masuk akal atau tidak masuk akal? Suatu hal yang sangat penting adalah perhatikan satuan, serta cek penyelesaiannya.

Menurut Polya (dalam Endang S.W dan Sri Harmini, 2011: 124-125), langkah-langkah yang pelu diperhatikan dalam pemecahan masalah yakni :

Pemahaman masalah

Dalam hal ini masalah harus bisa lebih di mengerti dan dipahami serta deketahui apa yang dikehendaki dari masalah tersebut. Cara memahami masalah itu sendiri dapat dilakukan dengan cara berikut : Membaca berulang-ulang agar dapat memahami kata demi kata, kalimat demi kalimat. Mengidentifikasi masalah yang diketahui. Mengidentifikasi apa yang ditanyakan dari masalah tersebut. Fokus terhadap masalah. Sebaiknya tidak menambah hal-hal yang tidak ada agar tidak menimbulkan masalah yang berbeda yang seharusnya tidak dibutuhkan. Perencanaan pemecahan masalah
Melihat adakah hubungan yang diketahui tersebut dengan yang dintanyakan, lalu menghubungkan keduanya sehingga mendapat pemecahan masalah. Berikut ini adalah strategi pemecahan masalah menurut Wheeler dalam Endang S.W dan Sri Harmini (2011: 125): 1) Membuat suatu tabel atau gambar. 2) Menduga, melakukan tes, dan memperbaiki. 3) Mencari pola permasalahan. 4) Menyatakan kembali permasalahan. 5) Menggunakan penalaran, variabel, dan persamaan. 6) Menyederhanakan masalah. 7) Menghilangkan situasi yang tidak mungkin. 8) Bekerja mundur. 9) Menyusun model. 10) Mengunakan algoritma, penalaran tidak langsung, sifat-sifat bilangan, kasus atau membagi masalah dengan bagian-bagiannya. 11) Mengkoreksi semua kemungkinan. 12) Menggunakan rumus. 13) Menyelesaikan masalah yang ekuivalen. 14) Menggunakan simetri dan informasi yang diketahui untuk mengembangkan informasi baru. 15) Melaksanakan perencanaaan pemecahan masalah . 16) Melihat kembali kelengkapan pemecahan masalah.

\section{Kerangka Berfikir}

Dalam penelitian ini, penulis akan meneliti tentang proses berpikir kreatif siswa yang mengikuti bimbingan belajar dalam menyelesaikan soal-soal ujian nasional. Setiap anak memiliki kemampuan berpikir yang berbeda-beda, ada siswa yang memiliki kemampuan tinggi, sedang dan rendah. Dalam menyelesaikan soal-soal ujian nasional ada banyak cara yang mereka pakai. Seringkali dalam bimbingan belajar, para siswa di ajarkan bagaimana caracara menyelesaikan soal-soal ujian nasional dengan cepat untuk menghemat waktu. Langkah-langkah tersebutlah yang akan diteliti sebagai proses berpikir kreatif siswa yang mengikuti bimbingan belajar.

Dalam penelitian ini, pemilihan subyek dibagi menjadi tiga kategori, yaitu subyek yang berkemampuan tinggi, sedang dan rendah. Oleh karena 
itu sebelum melakukan penelitian, maka kita observasi terlebih dahulu agar mendapatkan data subyek-subyek yang akan kita teliti. Penentuan tinggi, sedang dan rendahnya kemampuan subyek diukur dari hasil tryout yang dilakukan bimbingan belajar yang stelah dilakukan sebelumnya. Setelah melakukan pemilihan subyek, peneliti akan melakukan tes dan wawancara.

Data yang kita peroleh yaitu melalui tes dan wawancara. Dari data yang diperoleh, kita perlu menguji data tersebut apakah valid atau tidak. Jika data tersebut valid, maka dapat dilakukan analisis data. Akan tetapi, jika data tersebut tidak valid maka kita perlu menguji lagi dengan memberikan tes ulang dengan materi dan tipe soal yang sama kepada siswa. Hal tersebut dilakukan sampai didapatkan data yang valid sehingga dapat dilakukan tahap analisis data. Dari kegiatan analisis data, akan dihasilkan bagaimana proses berpikir kreatif siswa yang mengikuti bimbingan belajar matematika dalam menyelesaikan soal-soal ujian nasional.

\section{METODOOGI PENELITIAN}

Penelitian dilakukan pada siswa kelas IX SMP yang mengikuti bimbingan belajar di bimbingan belajar Madani dan LP3i dan dilaksanakan secara keseluruhan mulai Febuari 2013 sampai dengan Juli 2013. Penelitian ini menggunakan jenis penelitian kualitatif. Dalam pebelitian ini yang menjadi sumber data adalah siswa kelas XI SMP yang mengikuti bimbingan belajar di Kota Madiun yang terdiri dari 6 orang siswa. Penentuan subyek dilakukan secara purposive, yaitu dipilih dengan pertimbangan dan tujuan tertentu. pengambilan subyek berdasarkan tiga kategori yaitu siswa yang berkemampuan tinggi, sedang, dan rendah. Ketiga kategori tersebut dipilih berdasarkan nilai tryout yang telah diperoleh pada tes sebelumnya. kategori tinggi yaitu siswa dengan nilai tryout $\geq$ 80, kategori sedang atau cukup dengan nilai tryout antara $70-80$, kategori nilai rendah atau kurang dengan nilai tryout $\leq 70$.

Pada penelitian ini, teknik pengumpulan data yang digunakan adalah metode tes dan wawancara. Tes yang digunakan berbentuk tes uraian dengan jumlah soal sebanyak 2 butir dengan waktu 20 menit dimana soal-soal tersebut merupakan soal-soal yang diambil dari soal-soal ujian nasional. Sedangkan wawancara dilakukan secara terbuka dan tidak berstruktur. Tujuan diadakannya tes dan wawancara adalah supaya diperoleh data tentang langkahlangkah dan proses penyelesaian permasalahan matematika, sehingga diperoleh gambaran proses berpikir kreatif siswa dalam menyelesaikan soalsoal ujian nasional. Dari data yang diperoleh, perlu dilakukan pengujian data terlebih dahulu bahwa data tersebut valid atau tidak. Jika data tersebut valid, maka dapat dilakukan analisis data. Akan tetapi, jika data tersebut tidak valid maka perlu dilakukan pengujian lagi dengan cara siswa diberi tes ulang dengan materi dan tipe soal yang sama.

Penelitian yang dilaksanakan dibagi menjadi tiga tahap yaitu tahap persiapan, pelaksana, dan tahap pengolahan data dan penyusunan laporan. Untuk menguji keabsahan data dalam penelitian menggunakan trianggulasi teknik yaitu menggunakan teknik pengumpulan data yang berbedabeda untuk mendapatkan data dari sumber yang sama. Data yang diperoleh selanjutnya akan dianalisis dengan cara mereduksi data, menyajikan data lalu membuat kesimpulan dan melakukan verifikasi. Dari kegiatan analisis data, akan dihasilkan proses berpikir siswa SMP yang mengikuti bimbingan belajar dalam menyelesaikan soal-soal ujian nasional

\section{HASIL PENELITIAN}

\section{Temuan Penelitian}

Berdasarkan jawaban tes tulis yang kemudian diseimbangkan dengan wawancara dari keenam subyek 
diperoleh kecenderungan bahwa proses berpikir kreatif siswa yang mengikuti bimbingan belajar dalam mengerjakan soal-soal ujian nasional cenderung baik. Pada subyek kategori tinggi dan sedang, ditemukan keduanya dalam proses berpikir mampu menemukan banyak alternatif cara yang ditempuh dalam menyelesaikan soal. Sedangkan pada subyek kategori rendah, ditemukan paling tidak satu cara dalam menyelesaikan soal. Akan tetapi dalam kategori ketiga-tiganya, ditemukan bahwa siswa yang mengikuti bimbingan belajar menggunakan cara cepat atau singkat dalam mengerjakan soal-sakata 2 tersebut, Hal ini ditunjukkan dengan semua jawaban subyek, mereka tidak menuliskan apa yang diketahui, yang ditanyakan, dan kalimat kesimpulan akhir.

\section{PEMBAHASAN}

Berdasarkan dari hasil analisis pada tahap pemahaman masalah terlihat bahwa : 1) dalam tahap pemahaman masalah siswa SMP yang mengikuti bimbingan belajar memiliki kecenderungan mengumpulkan informasi atau data dengan baik. 2) siswa SMP yang mengikuti bimbingan belajar dengan kategori subyek tinggi dan sedang memiliki kecenderungan pemahaman yang lebih baik dalam mengidentifikasi masalah, sedangkan subyek kategori rendah memiliki kecenderungan yang cukup baik. 3) dalam pemahaman masalah, siswa SMP yang mengikuti bimbingan belajar untuk subyek kategori tinggi dan sedang memiliki kecenderungan pemahaman yang baik dalam proses mengistirahatkan sejenak pikiran yang berlangsung dibawah sadar. Sedangnkan subyek kategori rendah memiliki pamahaman masalah yang cukup. 4) adanya keberagaman proses berpikir kreatif siswa SMP yang mengikuti bimbingan belajar dalam pemahaman masalah pada saat menemukan ide atau inspirasi. 5) dalam proses berpikir kreatif siswa SMP yang mengikuti bimbingan belajar dengan subyek kategori tinggi dan sedang memiliki pemahaman yang baik dalam mengevaluasi pemecahan masalah yang telah menjadi solusi, sedangkan subyek kategori rendah belum dapat disimpulkan secara umum. 6) siswa SMP yang mengikuti bimbingan belajar memiliki pemahaman yang baik dalam memutuskan solusi dlam menyelesaikan soal-soal ujian nasional. 7) siswa SMP yang mengikuti bimbingan belajar cenderung memiliki pemahaman yang cukup baik dalam mengambil langkahlangkah solusi dalam menyelesaikan soal-soal ujian nasional.

Berdasarkan pada tabel di atas pada tahap perencanaan pemecahan masalah terlihat bahwa : 1) Siswa SMP yang mengikuti bimbingan belajar dengan kategori subyek tinggi dan sedang memiliki kecenderungan perencanaan pemecahan masalah yang baik dalam mengidentifikasi masalah, sedangkan subyek kategori rendah memiliki kecenderungan yang cukup baik. 2) Dalam perencanaan pemecahan masalah, siswa SMP yang mengikuti bimbingan belajar untuk subyek kategori tinggi dan sedang memiliki kecenderungan perencanaan pemecahan masalah yang baik dalam proses mengistirahatkan sejenak pikiran yang berlangsung dibawah sadar. Sedangkan subyek kategori rendah memiliki perencanaan pemecahan masalah yang cukup. 3) adanya keberagaman proses berpikir kreatif siswa SMP yang mengikuti bimbingan belajar dalam peperencanaan pemecahan masalah pada saat menemukan ide atau inspirasi. 4) Siswa SMP yang mengikuti bimbingan belajar cenderung memiliki perencanaan pemecahan masalah yang cukup baik dalam mengambil langkah-langkah solusi dalam menyelesaikan soal-soal ujian nasional.

Berdasarkan pada tabel di atas, pada tahap melaksanakan perencanaan pemecahan masalah terihat bahwa: 1) Adanya keberagaman proses berpikir kreatif siswa SMP yang mengikuti bimbingan belajar dalam melaksanakan 
perencanaan pemecahan masalah pada saat menemukan ide atau inspirasi. 2) Subyek kategori tinggi dan sedang memiliki kemampuan yang baik dalam melaksanakan perencanaan pemecahan masalah, sedangkan subyek kategori rendah belum dapat disimpulkan secara umum. 3) Siswa SMP yang mengikuti bimbingan belajar cenderung melaksanakan perencanaan pemecahan masalah yang cukup baik dalam mengambil langkah-langkah solusi dalam menyelesaikan soal-soal ujian nasional.

Berdasarkan pada tabel di atas, pada tahap melihat kembali kelengkapan pemecahan masalah terlihat bahwa :1) dengan subyek kategori tinggi dan sedang memiliki kemampuan yang baik dalam melihat kembali kelengkapan pemecahan masalah sedangkan subyek kategori rendah belum dapat disimpulkan secara umum. 2) SMP yang mengikuti bimbingan belajar memiliki kemampuan yang baik dalam melihat kembali kelengkapan pemecahan masalah ketika menyelesaikan soal-soal ujian nasional. 3) siswa SMP yang mengikuti bimbingan belajar cenderung memiliki kemampuan yang baik melihat kembali kelengkapan pemecahan masalah ketika menyelesaikan soal-soal ujian nasional.

\section{PENUTUP}

\section{Simpulan}

Berdasarkan kajian teori yang didukung oleh hasil penelitian, maka dapat disimpulkan bahwa proses berpikir siswa dikatakan kreatif apabila dapat melewati tahap-tahap berpikir kreatif dengan baik. Adapun tahap-tahap yang dimaksud adalah tahap persiapan, inkubasi, iluminasi, verifikasi dan aplikasi. Secara rinci, masing-masing kategori subyek memiliki kecenderungan proses berpikir kretaif sebagai berikut :

Kategori subyek tinggi

Pada tahap orientasi, subyek mampu mengumpulkan data dan mendefinisikan masalah dengan baik. Pada tahap inkubasi, subyek telah mampu melewatinya dengan baik. Pada tahap iluminasi, subyek mampu memunculkan ide dengan baik. Pada tahap verifikasi, subyek mengevaluasi pemecahan masalah dan memutuskan solusi dengan baik.

Kategori subyek sedang

Pada tahap orientasi subyek mengumpulkan data serta mendefinisikan masalah dengan baik. Pada tahap inkubasi, subyek mampu melewatinya dengan baik. Pada tahap iluminasi, belum bisa ditentukan dengan jelas karena masih ditemukan proses berpikir yang beragam. Pada tahap verifikasi, subyek telah mampu mengevaluasi pemecahan masalah dan memutuskan solusi dengan baik. Sedangkan pada tahap aplikasi, subyek mengambil langkah-langkah solusi dengan cukup.

Kategori subyek rendah

Pada tahap orientasi, subyek sudah mampu mengumpulkan data dengan baik, akan tetapi dalam mengidentifikasi masalah subyek melakukannya dengan cukup baik. Pada tahap inkubasi,subyek telah mampu melewatinya dengan cukup baik. Pada tahap verifikasi belum bisa disimpulkan secara umum karena subyek kategori rendah masih ditemukan proses berpikir yang beragam. Sedangkan pada tahap aplikasi, subyek telah mampu mengambil langkah-langkah solusi dengan cukup baik.

Dari hasil analisis tes dan wawancara pada langkah-langkah pemecahan masalah yaitu pemahaman masalah, perencanaan pemecahan masalah, melaksanakan perencanaan pemecahan masalah, dan melihat kembali kelengkapan pemecahan masalah dapat dilihat sebagai berikut: 1) Pada tahap pemahaman masalah, Siswa SMP yang mengikuti bimbingan belajar sudah mampu mengumpulkan informasi dan mengambil langkah-langkah solusi dengan baik. Pada proses berpikir kreatif siswa yang mengikuti bimbingan belajar melewati masa inkubasi, mengidentifikasi masalah, menemukan ide dan mengevaluasi pemecahan 
masalah dengan cukup baik. Sedangkan tahap pemahaman masalah, siswa yang mengikuti bimbingan belajar sudah cukup baik dalam mengambil langkahlangkah solusi. 2) Tahap perencanaan pemecahan masalah, Siswa yang mengikuti bimbingan belajar mampu mengumpulkan informasi dan mengidentifikasi masalah dengan cukup baik. Pada proses berpikir kreatif siswa yang mengikuti bimbingan belajar dapat menemukan ide atau inspirasi dengan cukup baik dan mengambil langkahlangkah solusi dengan cukup baik. 3) Tahap melaksanakan perencanaan pemecahan masalah Siswa yang mengikuti bimbingan belajar dalam menemukan ide atau inspirasi serta mengevaluasi pemecahan masalah sudah cukup baik. Pada proses berpikir kreatif siswa yang mengikuti bimbingan belajar ketika mengambil langkah-langkah solusi dapat menerapkannya dengan sistematis tetapi tidak dilakukan secara rinci 4) Tahap melihat kembali kelengkapan pemecahan masalah, Siswa yang mengikuti bimbingan belajar sudah cukup baik dalam mengevaluasi pemecahan masalah yang telah menjadi solusi dan mengambil langkah-langkah solusi. Pada proses berpikir kreatif siswa yang mengikuti bimbingan belajar telah dapat memutuskan solusi secara mandiri tanpa bantuan orang lain.

\section{Saran}

Berdasarkan kesimpulan, penulis menawarkan beberapa saran untuk mengatasi permasalahan yang dialami pada saat penelitian dilakukan. Pada tahap iluminasi untuk subyek kategori sedang dan tahap verifikasi untuk kategori rendah masih belum bisa disimpulkan proses berpikir kreatifnya secara umum, oleh karena itu perlu dilakukan tes ulang dengan soal yang berbeda serta wawancara berulang-ulang agar diperoleh data yang valid sehingga dapat diperoleh kesimpulan secara umum.

Ketika melakukan wawancara siswa masih merasa canggung dan malumalu karena belum pernah diwawancarai sebelumnya, oleh karena itu wawancara menjadi terkesan resmi. Bagi peneliti yang ingin meneliti disarankan agar melakukan wawancara minimal 2 kali agar diperoleh hasil yang lebih valid. Selain itu bagi peneliti yang sejenis disarankan menggunakan 5 kriteria indikator dalam penelitian kualitatif yaitu sangat baik, baik, cukup, kurang, dan sangat kurang.

\section{Kelemahan dan Keterbatasan Penelitian}

Penelitian ini memiliki kelemahan yaitu proses berpikir kreatif pada subyek kategori sedang dan rendah masih belum bisa disimpulkan secara umum karena masih ditemukan indikator yang beragam.

Penelitian ini memiliki keterbatasan antara lain yaitu penelitian hanya dilakukan pada dua bimbingan belajar saja, sehingga data yang diperoleh kurang beragam dan kurang valid. Oleh karena itu perlu dilakukan penelitian lanjutan yang melibatkan subyek dari situasi sosial lain yang lebih luas untuk mengetahui apakah akan memberi hasil yang sama atau berbeda.

\section{DAFTAR PUSTAKA}

Abin Syamsuddin. 2009. Psikologi Pendidikan-Perangkat Sistem Pengajaran Modul. Bandung: Remaja Rosdakarya.

Agus Sujanto. 2004. Psikologi Umum. Jakarta: Bumi Aksara.

Anisah B dan Syamsu Mappa. 2011. Teori Belajar Orang Dewasa. Bandung: Remaja Rosdakarya.

Badan Standar Nasional Pendidikan. 2013. Prosedur Operasi Standar penyelenggaraan ujian nasional sekolah menengah pertama/madrasah tsanawiyah, sekolah menengah pertama luar biasa, sekolah menengah atas/madrasah aliyah, sekolah menengah atas luar biasa, sekolah menengah kejuruan, serta pendidikan kesetaraan program paket a/ula, program 
paket $\mathrm{b} /$ wustha, program paket c, dan program paket c kejuruan tahun pelajaran 2012/2013 badan standar nasional pendidikan 2013. Jakarta: Departemen Pendidikan dan Kebudayaan.

Black, James A. dan Dean J. Champion, 2009. Metode dan Masalah Penelitian Sosial. Bandung: Refika Aditama.

Delphie, Bandi. 2009. Matematika Untuk Anak Berkebutuhan Khusus. Klaten: Intan Sejati.

Desmita. 2012. Psikologi Perkembangan. Bandung: Remaja Rosdakarya.

Dian Indah Purnamasari. 2012. Profil Berpikir Kreatif Siswa Kelas V SD Yang Mengikuti Les dalam Menyelesaikan Soal Pecahan. Skripsi tidak diterbitkan. Madiun: Program Studi Pendidikan Matematika dan Ilmu Pengetahuan Alam.

Herman Hudojo. 2005. Pengembangan Kurikulum dan Pembelajarn Matematika. Malang: Universitas Negeri Malang.

Imam Gunawan. 2011. Evaluasi Program Pembelajaran. Jurnal Pendidikan, 17(1): 55).

Jalaludin Rakhmat. 2007. Psikologi Komunikasi. Bandung: Remaja Rosdakarya.

Kettut, Sukardi. 2011. Pengantar Pelaksanaan Program Bimbingan Dan Konseling Di Sekolah. Jakarta: Rineka Cipta.

King, Laura. 2012. Psikologi UmumSebuah Pandangan Apresiatif. Jakarta: Salemba Humanika.

Made Wena. 2011. Strategi Pembelajaran Inovatif Kontenporer. Jakarta: Bumi Aksara.

Mohammad Ali dan M. Asrori. 2005. Psikologi Remaja. Jakarta: Bumi Aksara.

Mustaqim dan Abdul W. 2003. Psikologi Pendidikan. Jakarta: Rineka Cipta.
Ngalim Purwanto. 2007. Psikologi Pendidikan. Bandung: Remaja Rosdakarya.

Oemar Hamalik. 1992. Psikologi Belajar dan Mengajar. Bandung: Sinar Baru Bandung.

Peraturan Menteri Pendidikan dan Kebudayaan Republik Indonesia Nomor 3 Tahun 2013 tanggal 18 Januari 2013 tentang Kriteria Kelulusan Peserta Didik Dari Satuan Pendidikan Dan Penyelenggaraan Ujian Sekolah/Madrasah/Pendidikan Kesetaraan Dan Ujian Nasional.

Poerwadarminta, W.J.S. 2007. Kamus Umum Bahasa Indonesia. Jakarta: Balai Pustaka.

Santrock, John W. 2009. Psikologi Pendidikan. Jakarta: Salemba Humanika.

Shaleh, Abdul R. 2009. Psikologi Suatu Pengantar Dalam Perspektif Islam. Jakarta: Prenada Media Group.

Slameto. 2010. Belajar Dan FaktorFaktor Yang Mempengaruhinya. Jakarta: Rineka Cipta.

Sudarwan Danim. 2011. Perkembangan Peserta Didik. Bandung: Alfabeta.

Sugiyono. 2006. Metode Penelitian Pendidikan (Pendekatan Kuantitatif, Kualitatif dan R\&D). Bandung: Alfabeta.

Suharsimi Arikunto. 2010. Prosedur Penelitian Suatu Pendekatan Praktik. Jakarta: Rineka Cipta.

Sukardi, Ketut. 2011. Pengantar Pelaksanaan Program Bimbingan Dan Konseling Di Sekolah. Jakarta: Rineka Cipta.

Sukardjono. 2007. Hakikat dan Sejarah Matematika. Jakarta Universitas Terbuka.

Sumadi Suryabrata. 2004. Psikologi Pendidikan. Jakarta: Rajawali.

Uhar Suharsaputra. 2012. Metode Penelitian Kuantitatif, 
Kualitatif, dan Tindakan. Bandung: Refika Aditama.

Winarni, Endang $\mathrm{H}$ dan Sri Harmini.2011. Matematika untuk PGSD. Bandung: Remaja Rosdakarya.
Wirawan Sarwono, Sarlito. 2009. Pengantar Psikologi Umum. Jakarta: Rajawali Pers.

Wowo Sunaryo. 2011. Taksonomi Berpikir. Bandung: Remaja Rosdakarya. 